Phinisi Integration Review
Vol. 1, No.2, Agustus 2018 Hal 98-111
Website: http://ojs.unm.ac.id/pir

\title{
Pengaruh Model Pembelajaran Dan Motivasi Belajar Terhadap Hasil Belajar Sejarah Indonesia Siswa Madrasah Aliyah
}

\author{
Isnain \\ Pendidikan Sejarah, Program Pascasarjana \\ Universitas Negeri Makassar \\ email: nainputrasalam@gmail.com
}

\begin{abstract}
The study aims at examining the difference of Indonesian History learning result between cooperative learning model of Jigsaw type and Expository type by examining students' learning motivation and interaction between learning model and learning motivation of students on Indonesia History learning result. The result of hypothesis test reveals that (1) there are differences of influences between utilization of cooperative learning model of Jigsaw type and Expository learning model on Indonesian History learning result because the significance value is smaller than $\alpha=0.05$; (2) there are differences of influences between students who have high learning motivation and students who have low learning motivation on Indonesian History learning result; (3) there are influence interactions between the utilization of learning model and learning motivation on Indonesian History learning results; (4) there are differences of Indonesian History learning result between students who were taught by using Cooperative Learning model with Jigsaw type and Expository learning model for students who have high learning motivation; (5) there are differences of Indonesian History learning results between students who were taught by using Cooperative learning model of Jigsaw type and Expository learning model for students who have low learning motivation; (6) the differences of Indonesian History learning results between students who have high learning motivation and the ones who have low motivation for students who were taught by using Cooperative learning model of Jigsaw type; and (7) the differences of Indonesian History learning results between students who have high learning motivation and the ones who have low motivation for students who were taught by using Expository learning model.
\end{abstract}

Keywords:Cooperative Learning Model of Jigsaw Type and Expository, Learning Motivation, Learning Result.

\section{PENDAHULUAN}

Peranan ilmu pengetahuan dan teknologi saat ini telah menyebabkan perubahan mendasar dalam kehidupan bangsa. Dalam menghadapi berbagai permasalahan yang timbul dari persaingan global maka diperlukan sumber daya manusia Indonesia yang handal dan berkualitas melalui pembaharuan sistem pendidikan dan penyempurnaan kurikulum. 
Untuk mewujudkan tujuan pendidikan, diperlukan usaha untuk meningkatkan proses pembelajaran agar diperoleh hasil yang efektif dan efisien. Disini pendidikan tidak hanya outputnya, melainkan harus dilihat juga dari segi bagaimana proses pembelajaran itu diselenggarakan yang membutuhkan perencanaan dan pelaksanaan yang sangat matang agar tercapai hasil yang maksimal. Salah satu caranya adalah dengan menerapkan model pembelajaran yang baru dan dapat menarik minat belajar siswa di dalam kelas.

Sejak diberlakukan Kurikulum 2013 di Tingkat Madrasah Aliyah Kabupaten Takalar pada Tahun Pelajaran 2014/2015 mata pelajaran Sejarah Indonesia menjadi salah satu mata pelajaran wajib bagi setiap jenjang kelas peminatan. Muatan materi dalam pelajaran Sejarah Indonesia menjadi kendala bagi siswa seperti halnya materi Terbentuknya Kepulauan Indonesia dan Mengenal Manusia Purba pada semester ganjil yang lebih banyak mempelajari materi yang berasal dari ilmu geografi serta materi Islamisasi dan Silang Budaya di Nusantara pada semester genap yang lebih banyak materinya berasal dari sosial budaya.

Pembelajaran Sejarah Indonesia yang menyenangkan mungkin sangat jarang ditemui dalam kegiatan belajar mengajar. Ini dapat dilihat masih banyak guru Sejarah Indonesia yang menggunakan metode ceramah di sekolah contohnya, seorang guru lebih berperan aktif, sedangkan siswa menjadi pasif. Sehingga siswa beranggapan Sejarah Indonesia dianggap tidak penting dan dianggap kurang memiliki improvisasi seperti halnya Ilmu Eksak dengan permainan rumusnya yang membuat siswa semakin tertantang untuk mencoba dan menganalisa. Membaca atau mempelajari Sejarah Indonesia diibaratkan seperti membaca dongeng dengan rentetan peristiwa, tahun dan tempat peristiwa, maupun nama tokoh/pelaku yang terlalu banyak dan sulit untuk diingat. Maka dari itu ini menjadi persoalan dan masalah bagi kita untuk tidak menerapkan metode ceramah. Karena sesungguhnya guru hanyalah fasilitator, motivator, organisator dan informator.

Kurangnya minat dan motivasi belajar siswa pada mata pelajaran Sejarah Indonesia di Madrasah Aliyah Bontomarannu dapat diamati dari hasil belajar siswa tahun pelajaran 2015/2016 yang rata-rata memperoleh nilai dibawah Kriteria Ketuntasan Minimal (KKM) dengan perolehan nilai Ujian Akhir Semester
67,68 dari nilai standar KKM Mata Pelajaran yang ditetapkan 75. Dari permasalahan ini dipandang penting untuk melakukan penelitian tentang pengaruh model pembelajaran dan motivasi belajar terhadap hasil belajar siswa dalam menerima materi pelajaran Sejarah Indonesia.

Rendahnya nilai perolehan siswa menjadi petunjuk untuk mencari penyebab kelemahankelemahan siswa dalam menyerap materi pelajaran dengan melihat pembanding Model Pembelajaran Ekspositori sebagai model pembelajaran yang paling sering digunakan guru dalam mengajar dan Model Pembelajaran Kooperatif Tipe Jigsaw sebagai model pembelajaran baru yang akan dijadikan sebagai kelas eksperimen.

Merujuk dari perolehan nilai siswa tersebut maka pelajaran Sejarah Indonesia oleh sebagian siswa menganggap merupakan pelajaran yang dianggap membosankan karena hanya menceritakan tentang aspek kehidupan lampau yang metode mengajarnya hanya didominasi oleh ceramah atau penjelasan guru di depan kelas dan motivasi belajar Sejarah Indonesia siswa masih rendah dikarenakan kurangnya kemampuan siswa dalam memahami materi pelajaran.

Penyebab rendahnya nilai hasil belajar siswa di MA. Bontomarannu karena metode yang digunakan guru dalam mengajar kurang menarik dan cenderung monoton. Oleh karena itu, siswa tidak termotivasi dan malas untuk berpikir, Sehingga bisa mempengaruhi pula aktivitas belajar siswa. Oleh sebab itu, guru harus berupaya menggunakan strategi atau langkah-langkah pelajaran yang efektif dan menarik, sehingga memudahkan siswa dalam memahami materi yang diajarkan dengan anggapan bahwa Sejarah Indonesia merupakan pelajaran yang membosankan. Sejalan dengan itu, perlu dicoba terapkan sebuah model pembelajaran yang dapat membangkitkan motivasi belajar siswa, sehingga dapat meningkatkan hasil belajar siswa. Model pembelajaran yang akan digunakan yaitu Model Pembelajaran Kooperatif Tipe Jigsaw sebagai kelas eksperimen.

Secara umum, tujuan dari penelitian ini adalah meningkatkan prestasi belajar siswa dalam mata pelajaran Sejarah Indonesia di tingkat Madrasah Aliyah Bontomarannu. Adapaun tujuan khusus dari penelitian ini adalah untuk mengetahui Pengaruh Model Pembelajaran Kooperatif Tipe Jigsaw dan 
Motivasi Belajar Terhadap Hasil Belajar Sejarah Indonesia Siswa.

\section{METODE PENELITIAN}

Penelitian ini adalah penelitian kuantitatif dengan jenis penelitian Eksperimen yang sifatnya Quasi Experimental Design (desain eksperimen semu). Penelitian kuantitatif itu sendiri merupakan penelitian dengan data yang dianalisis berupa data kuantitatif. Jenis penelitian Quasi Eksperimental Designdidesain dengan menggunakan dua kelompok yaitu kelompok kontrol yang diajar dengan menggunakan Model Pembelajaran Ekspositori, dan kelompok eksperimen yaitu kelas yang diajar dengan menggunakan Model Pembelajaran Kooperaif Tipe Jigsaw.

Penelitian ini dilaksanakan di Kelas X Madrasah Aliyah Bontomarannu, Kabupaten Takalar. Subyek penelitian adalah siswa Kelas X Madrasah Aliyah Bontomarannu. Terdiri dari Kelas X Program Matematika dan Ilmu-Ilmu Alam dan Kelas X Program Ilmu-Ilmu Sosial

Penelitian ini menggunakan tiga variabel, yaitu variabel bebas, variabel moderator dan variabel terikat. Model Pembelajaran Kooperatif Tipe Jigsaw dan Model Pembelajaran Ekspositori sebagai variabel bebas dan motivasi belajar sebagai variabel moderator serta hasil belajar sebagai variabel terikat.

Desain penelitian ini menggunakan desain faktorial $2 \times 2$ dengan teknik analisis varian dua jalur (ANAVA), penelitian ini mempunyai dua variabel bebas dan satu variabel terikat. Variabel bebas pertama (variabel perlakuan) adalah model pembelajaran, variabel bebas kedua (variabel atribut) adalah motivasi belajar, sedang variabel terikat adalah hasil belajar Variabel bebas terdiri dari Model Pembelajaran Kooperatif Tipe Jigsaw (A1) dan Model Pembelajaran Ekspositori (A2). Variabel moderator terdiri dari motivasi tinggi (B1) dan motivasi rendah (B2).

Populasi penelitian ini adalah semua siswa Kelas X Madrasah Aliyah (MA) Bontomarannu Kabupaten Takalar yang terdiri atas 2 kelas yaitu Kelas X Matematika dan Ilmu-Ilmu Alam (MIA) dan Kelas X Ilmu-Ilmu Sosial (IIS). Adapun jumlah secara keseluruhan siswa Kelas $X$ adalah 43 orang. Dimana Kelas X MIA dengan jumlah siswa sebanyak 23 dan Kelas $X$ IIS juga jumlah siswa sebanyak 20 orang.

Pengambilan sampel dalam penelitian ini dengan teknik probability sampling dengan menggunakan proportional simple random sampling. Probability teknik pengambilan sampel yang memberikan peluang yang sama bagi setiap unsur (anggota) populasi untuk dipilih menjadi anggota sampel, sedangkan simple random sampling karena pengambilan anggota sampel dari populasi dilakukan secara acak tanpa memperhatikan strata yang ada dalam populasi itu (Sugiyono, 2011: 63-64).

Besarnya sampel dalam penelitian ini ditentukan dengan rumus Slovin dengan pertimbangan bahwa populasi relatif homogen/seragam sehingga tidak terlalu diperlukan untuk distratifikasi. Selain itu, penggunaan rumus ini akan menghasilkan jumlah sampel yang relative lebih besar dibanding beberapa rumus lain, sehingga karakteristik dari populasi akan lebih terwakili. Rumus selengkapnya sebagai berikut:

$$
n=\frac{N}{1+N e^{2}}
$$

Populasi 43 siswa dan presisi yang ditetapkan atau tingkat signifikansi 0,05 , maka besarnya sampel pada penelitian ini adalah:

$$
\begin{aligned}
& n=\frac{N}{1+N e^{2}} \\
& n=\frac{43}{1+43.0,05^{2}} \\
& =38,826 \text { dibulatkan menjadi } 39
\end{aligned}
$$

Jadi jumlah keseluruhan responden dalam penelitian ini adalah 39 siswa. Alasan menggunakan rumus tersebut adalah untuk mendapat sampel yang representative dan lebih pasti atau mendekati populasi yang ada.

Instrumen Penelitian ini adalah tes hasil belajar, angket motivasi belajar.

1. Tes Hasil Belajar Sejarah Indonesia

Instrumen hasil belajar Sejarah Indonesia disusun berdasarkan Kurikulum 2013 Kelas X Semester Ganjil sebanyak 30 butir soal dalam bentuk pilihan ganda. Data hasil belajar siswa dikumpulkan melalui tes dengan menggunakan instrumen tes. Tes hasil belajar Sejarah Indonesia diberikan pada kelas kontrol dan kelas eksperimen dengan jumlah responden sebanyak 43 siswa.

\section{Angket Motivasi Belajar}

Metode angket atau kuesioner adalah suatu daftar yang berisikan rangkaian pertanyaan dan pernyataan mengenai sesuatu masalah atau bidang yang akan diteliti. Untuk memperoleh data, angket disebarkan kepada responden terutama pada penelitian survei. Kuesioner yang digunakan dalam penelitian ini adalah angket dalam bentuk check list. Teknik angket 
digunakan untuk menentukan tingkatan kecerdasan emosional dan motivasi pada diri siswa. Saat pelaksanaan penelitian, siswa diarahkan untuk mengisi angket berdasarkan keadaan diri mereka sebenarnya yang kemudian siswa dapat diklasifikasikan tingkatan motivasi yang dimilikinya dalam mengikuti materi pelajaran Sejarah Indonesia. Klasifikasi tingkatan motivasi belajar siswa dapat dikategorikan dalam bentuk motivasi tinggi dan motivasi rendah.

Data adalah unit informasi yang direkam media yang dapat dibedakan dengan data lain, dapat dianalisis dan relevan dengan program tertentu. Pengumpulan data adalah prosedur yang sistematik dan standar untuk memperoleh data yang diperlukan.

Untuk mengumpulkan data penelitian, penulis menggunakan metode-metode antara lain sebagai berikut:

Tes hasil belajar dalam bentuk pilihan ganda sebanyak 40 butir soal, digunakan untuk memperoleh data gambaran tentang hasil pretest dan post-test antara kelas eksperimen yang diberi perlakuan dengan kelas kontrol yang tidak diberi perlakuan. Apakah terdapat perbedaan yang cukup signifikan atau tidak. Tes belajar yang berkaitan dengan materi Sejarah Indonesia yang dikembangkan oleh peneliti sendiri. Pelaksanaan tes ini di ambil sampel 43 responden yang terdiri dari 2 (dua) kelas yaitu kelas X MIA dan X IIS. Tes hasil belajar ini dilakukan untuk mengetahui pengaruh model pembelajaran terhadap hasil belajar Sejarah Indonesia di kelas kontrol dan kelas eksperimen.

Metode angket atau kuesioner adalah suatu daftar yang berisikan rangkaian pertanyaan dan pernyataan mengenai sesuatu masalah atau bidang yang akan diteliti. Untuk memperoleh data, angket disebarkan kepada responden terutama pada penelitian survei. Kuesioner yang digunakan dalam penelitian ini adalah angket dalam bentuk check list. Teknik angket digunakan untuk menentukan tingkatan kecerdasan emosional dan motivasi pada diri siswa. Saat pelaksanaan penelitian, siswa diarahkan untuk mengisi angket berdasarkan keadaan diri mereka sebenarnya yang kemudian siswa dapat diklasifikasikan tingkatan motivasi yang dimilikinya dalam mengikuti materi pelajaran Sejarah Indonesia. Klasifikasi tingkatan motivasi belajar siswa dapat dikategorikan dalam bentuk motivasi tinggi dan motivasi rendah.
Data yang dikumpulkan akan dianalisis secara deskriptif dan secara inferensial. Statistika deskriptif adalah statistika yang digunakan untuk menganalisis data dengan cara mendeskripsikan atau menggambarkan data yang telah terkumpul sebagai mana adanya, tanpa bermaksud membuat kesimpulan yang berlaku umum (Sugiyono, 2007:207).

Dalam penelitian ini, analisis statistik deskriptif digunakan untuk mendeskripsikan hasil belajar sejarah siswa pada setiap kelompok yang telah dipilih. Analisis ini meliputi, nilai mean (rata-rata), standar deviasi, nilai maksimum, nilai minimum, dan tabel distribusi frekuensi serta histogram.

Statistik inferensial untuk menguji hipotesis penelitian dengan menggunakan Software SPSS 20.0 dengan analisis variansi dua jalur Sebelum menguji hipotesis penelitian, terlebih dahulu dilakukan uji prasyarat hipotesis berupa uji normalitas dan uji homogenitas.

a. Pengujian prasyarat analisis

1. Uji Normalitas

Uji Normalitasdatadipergunakanuntuk memastikanbahwadatapenelitianmemiliki distribusinormal.Pengujiannormalitasdatainidila kukandengan melihat nilai signifikansi pada uji Kolmogorov-Smirnov yang dilakukan pada penilaian pretest kelas kontrol dan kelas eksperimen

2. Uji Homogenitas

Uji homogenitas dimaksudkanuntuk mengetahui apakah data sampel diperolehdaripopulasiyang bervarianshomogenatautidak.Pengujianhomogen itas dilakukandenganmenggunakanuji $F$ dan uji Tukey (Tukey'sHSD) dengan menggunakan Software SSPS 20.0.

\section{HASIL DAN PEMBAHASAN}

Deskripsi Analisis Data

1. Deskripsi Rangkuman Data Hasil Belajar Sejarah Indonesia Siswa Kelas X Madrasah Aliyah Bontomarannu Kabupaten Takalar

Data penelitian menunjukkan bahwa: jumlah responden $(\mathrm{N})=43$ siswa dengan nilai tertinggi $=93,00$ dan nilai terendah $=56,00$, mean $(X)=74,51$, median $\left(M_{C}\right)=75,00$, Range $=37$, Trimmed Mean $=74,60$ yang artinya tidak terdapat outlier Standar Deviasi $(\mathrm{s})=$ 10,20, Standar error of mean $(\mathrm{SE})=1,556$. 
2. Deskripsi Data Hasil Belajar Sejarah Indonesia dengan Model Pembelajaran Kooperatif Tipe Jigsaw

Data penelitian menunjukkan bahwa: jumlah responden $(\mathrm{N})=23$ siswa dengan nilai tertinggi $=93,00$ dan nilai terendah $=56,00$, mean $(X)=$ 75,65 , median $(\mathrm{Mc})=80,00$,

Range $=37$, Trimmed Mean $=75,80$ yang artinya tidak terdapat outlier Standar Deviasi (s) $=13,03$, Standar error of mean $(\mathrm{SE})=2,717$.

3. Deskripsi Data Hasil Belajar Sejarah Indonesia dengan Model Pembelajaran Ekspositori

Data penelitian menunjukkan bahwa: jumlah responden $(\mathrm{N})=20$ siswa dengan nilai tertinggi $=83,00$ dan nilai terendah $=63,00$, mean $(\mathrm{X})=$ 73,20 , median $\left(\mathrm{M}_{\mathrm{C}}\right)=73,00$, Range $=$ 20Trimmed Mean= 73,22yang artinya tidak terdapat outlier Standar Devias $\mathrm{i}(\mathrm{s})=$ 5,47, Standar error of mean $(\mathrm{SE})=1,223$.

4. Deskripsi Data Hasil Belajar Sejarah Indonesia dengan Motivasi Belajar yang Tinggi

Data penelitian menunjukkan bahwa: jumlah responden $(\mathrm{N})=19$ siswa dengan nilai tertinggi $=93,00$ dan nilai terendah $=70,00$, mean $(X)=$ 81,00 , median $\left(\mathrm{M}_{\mathrm{C}}\right)=83,00$, range $=23$, Trimmed Mean $=80,94$ yang artinya tidak terdapat outlier Standar Deviasi $(s)=7,23$, Standar error of mean $(\mathrm{SE})=1,659$.

5. Deskripsi Data Hasil Belajar Sejarah Indonesia Dengan Motivasi Belajar yang Rendah

Data penelitian menunjukkan bahwa: jumlah responden $(\mathrm{N})=14$ siswa dengan nilai tertinggi $=70,00$ dan nilai terendah $=56,00$, mean $(\mathrm{X})=$ 62,07 , median $\left(\mathrm{M}_{\mathrm{C}}\right)=62,50$, range $=14$, Trimmed Mean $=61,96$ yang artinya tidak terdapat outlier Standar Deviasi $(\mathrm{s})=4,19$, Standar error of mean $(\mathrm{SE})=1,121$.

6. Deskripsi Data Hasil Belajar Sejarah Indonesia dengan Model Pembelajaran

Kooperatif Tipe Jigsaw dan Memiliki Motivasi Belajar yang Tinggi

Data penelitian menunjukkan bahwa: jumlah responden $(\mathrm{N})=10$ siswa dengan nilai tertinggi $=93,00$ dan nilai terendah $=83,00, \operatorname{mean}(\mathrm{X})$
$=87,10$, median $\left(\mathrm{M}_{\mathrm{C}}\right)=87,00$ Range $=10$, Trimmed Mean $=87,00$ yang artinya tidak terdapat outlier Standar Deviasi $(\mathrm{s})=3,10$, Standar error of mean $(\mathrm{SE})=0,982$.

7. Deskripsi Data Hasil Belajar Sejarah Indonesia dengan Model Pembelajaran Kooperatif Tipe Jigsaw dan Memiliki Motivasi Belajar yang Rendah

Data penelitian menunjukkan bahwa: jumlah responden $(\mathrm{N})=8$ siswa dengan nilai tertinggi $=$ 63,00 dan nilai terendah $=56,00$, Range $=7$, mean $(X)=59,37, \operatorname{median}\left(\mathrm{M}_{\mathrm{C}}\right)=60,00$, Trimmed Mean $=59,36$ yang artinya tidak terdapat outlier Standar Deviasi $(\mathrm{s})=2,97$ Standar error of mean $(\mathrm{SE})=1,051$

8. Deskripsi Data Hasil Belajar Sejarah Indonesia dengan Model Pembelajaran Ekspositori dan Memiliki Motivasi Belajar yang Tinggi

Data penelitian menunjukkan bahwa: jumlah responden $(\mathrm{N})=9$ siswa dengan nilai tertinggi $=80,00$ dan nilai terendah $=70,00$, mean $(X)=$ 74,22 , median $\left(\mathrm{M}_{\mathrm{C}}\right)=73$, Range $=10$, Trimmed Mean $=74,13$ yang artinya tidak terdapat outlier Standar Deviasi $(s)=2,94$, Standar error of mean $(\mathrm{SE})=0,982$.

9. Deskripsi Data Hasil Belajar Sejarah Indonesia dengan Model Pembelajaran Ekspositori dan Memiliki Motivasi Belajar yang Rendah

Data penelitian menunjukkan bahwa: jumlah responden $(\mathrm{N})=6$ siswa dengan nilai tertinggi $=$ 70,00 dan nilai terendah $=63$, mean $(\mathrm{X})=$ 65,66, median $(\mathrm{Mc})=65,00$, Range $=7$ Trimmed Mean $=65,57$ yang artinya tidak terdapat outlier, Standar Deviasi $(\mathrm{s})=2,50$, Standar error of mean $(\mathrm{SE})=1,021$

\section{Pengujian Persyaratan Analisa Data}

1. UjiNormalitas

Uji normalitas dilakukan untuk mengetahui apakah data terdistribusi normal atau tidak. Uji normalitas yang digunakan dalam penelitian ini adalah dengan menggunakan uji KolmogorovSmirnov. Uji dilakukan terhadap data pretest pada kelas kontrol dan kelas eksperimen. Hasil uji normalitas dapat dilihat dalam tabel berikut: 
Tabel 1. Uji Normalitas Kolmogorov-Smirnov dengan Kelas Kontrol dan Kelas Eksperimen

\begin{tabular}{l|l|r|r|r}
\hline \multicolumn{5}{c}{ Test Of Normality } \\
\hline \multicolumn{2}{c}{ Kelas } & \multicolumn{3}{|c}{ Kolmogorov-Smirnov } \\
\cline { 3 - 5 } \multicolumn{2}{c}{} & \multicolumn{1}{|c}{ Statistic } & \multicolumn{1}{c}{ df } & \multicolumn{1}{c}{ Sig. } \\
\hline \multirow{2}{*}{$\begin{array}{l}\text { Pre } \\
\text { Test }\end{array}$} & $\begin{array}{l}\text { Kelas } \\
\text { Kontrol }\end{array}$ & .179 & 20 & .093 \\
\cline { 2 - 5 } & $\begin{array}{l}\text { Kelas } \\
\text { Eksperimen }\end{array}$ & .118 & 23 & $.200^{*}$ \\
\hline
\end{tabular}

Dari tabel di atas terlihat bahwa nilai signifikansi untuk kelas kontrol maupun kelas eksperimen secara berturut-turut 0,093 dan 0,200 lebih besar dari 0,05 sehingga dapat dikatakan berdistribusi normal.

\section{Uji Homogenitas}

Uji homogenitas varians yang digunakan adalah dengan menggunakan uji $\mathrm{F}$ dan uji Tukey HSD. Dari hasil uji homogenitas variansi diperoleh dari populasi yang bervarians heterogen. Dari hasil pengolahan data dengan menggunakan Software SPSS 20.0 diperoleh data sebagai berikut:

Tabel 2. Uji Homogenitas Variansi

Test of Homogeneity of Variances

Hasil Belajar

\begin{tabular}{llll}
\hline $\begin{array}{l}\text { Levene } \\
\text { Statistic }\end{array}$ & df1 & df2 & Sig. \\
\hline 26.810 & 1 & 41 & .000 \\
\hline
\end{tabular}

Data di atas menunjukkan bahwa nilai signifikansinya lebih kecil dari 0,05 yang berarti data berasal dari populasi yang bervariansi homogen

Pengujian Hipotesis. Pengujian hasil analisis data yang diperoleh dari hasil perhitungan dengan menggunakan uji analisis Two Way Anova, Selanjutnya untuk menguatkan uji Anova dalam mengetahui interaksi yang terdapat dalam model pembelajaran dan motivasi yang dapat berpengaruh terhadap hasil belajar Sejarah Indonesia dapat diketahui dalam tabel di bawah ini:

Tabel 3. Hasil Uji Hipotesis Menggunakan Analisis ANOVA dua arah dengan bantuan Program SPSS 20.0 Tests of Between-Subjects Effects

\begin{tabular}{llllll}
\hline \multicolumn{5}{c}{ Dependent Variable: Hasil Belajar Sejarah } \\
\hline \multicolumn{1}{c}{ Source } & $\begin{array}{c}\text { Type III } \\
\text { Sum of } \\
\text { Squares }\end{array}$ & df & $\begin{array}{c}\text { Mean } \\
\text { Square }\end{array}$ & F & Sig. \\
\hline $\begin{array}{l}\text { Corrected } \\
\text { Model }\end{array}$ & $3809.306^{\mathrm{a}}$ & 3 & 1269.769 & 147.491 & .000 \\
\hline Intercept & 163102.429 & 1 & 163102.4 & 18945.35 & .000 \\
\hline motivasi & 2618.013 & 1 & 2618.013 & 304.098 & .000 \\
\hline model & 86.274 & 1 & 86.274 & 10.021 & .004 \\
\hline $\begin{array}{l}\text { motivasi } \\
* \text { model }\end{array}$ & 730.875 & 1 & 730.875 & 84.896 & .000 \\
\hline Error & 249.664 & 29 & 8.609 & & \\
\hline Total & 179770.000 & 33 & & & \\
\hline $\begin{array}{l}\text { Corrected } \\
\text { Total }\end{array}$ & 4058.970 & 32 & & & \\
\hline Pengujian & & & & & \\
\hline
\end{tabular}

Pengujian hipotesis selanjutnya menggunakan uji Tukey HSD.

Tabel di bawah ini adalah Tabel Tukey Post Hoc digunakan untuk menilai kategori manakah dari variable model pembelajaran dan motivasi belajar siswa yang memiliki perbedaan signifikan.

Tabel 4. Hasil Uji Lanjut Variabel Dependent (Hasil Belajar Sejarah Indonesia)

\begin{tabular}{|c|c|c|c|c|}
\hline (I) kelompok & $\begin{array}{c}(\mathrm{J}) \\
\text { kelompok }\end{array}$ & $\begin{array}{c}\text { Mean } \\
\text { Difference } \\
(\mathrm{I}-\mathrm{J})\end{array}$ & Std. Erro & r Sig. \\
\hline \multirow{3}{*}{$\begin{array}{l}\text { ekspository- } \\
\text { tinggi }\end{array}$} & $\begin{array}{l}\text { ekspository- } \\
\text { rendah }\end{array}$ & $8.55556^{*}$ & 1.54642 & .000 \\
\hline & jigsaw-tinggi & $-12.87778 *$ & 1.34814 & .000 \\
\hline & jigsaw-rendah & $14.84722 *$ & 1.42573 & .000 \\
\hline \multirow{3}{*}{$\begin{array}{l}\text { ekspository- } \\
\text { rendah }\end{array}$} & $\begin{array}{l}\text { ekspository- } \\
\text { tinggi }\end{array}$ & $-8.55556^{*}$ & 1.54642 & .000 \\
\hline & jigsaw-tinggi & $-21.43333^{*}$ & 1.51518 & .000 \\
\hline & jigsaw-rendah & $6.29167^{*}$ & 1.58461 & .002 \\
\hline \multirow{3}{*}{ jigsaw-tinggi } & $\begin{array}{l}\text { ekspository- } \\
\text { tinggi }\end{array}$ & $12.87778^{*}$ & 1.34814 & .000 \\
\hline & $\begin{array}{l}\text { ekspository- } \\
\text { rendah }\end{array}$ & $21.43333^{*}$ & 1.51518 & .000 \\
\hline & jigsaw-rendah & $27.72500^{*}$ & 1.39178 & .000 \\
\hline \multirow{3}{*}{ jigsaw-rendah } & $\begin{array}{l}\text { ekspository- } \\
\text { tinggi }\end{array}$ & $-14.84722 *$ & 1.42573 & .000 \\
\hline & $\begin{array}{l}\text { ekspository- } \\
\text { rendah }\end{array}$ & $-6.29167 *$ & 1.58461 & .002 \\
\hline & jigsaw-tinggi & $-27.72500 *$ & 1.39178 & .000 \\
\hline
\end{tabular}

Berdasarkan Tabel 4. Pada Mean Difference (I-J) terdapat tanda $(*)$ di sebelah kanan angka, hal ini berarti ada perbedaan signifikan antara model pembelajaran dan motivasi belajar terhadap hasil belajar Sejarah Indonesia.

Berdasarkan kedua tabel hasil belajar Sejarah Indonesia diatas dapat di interprestasikan hasil sebagai berikut:

a. Perbedaan yang signifikan antara penggunaan Model Pembelajaran Kooperatif 
Tipe Jigsaw dan Model Pembelajaran Ekspositori terhadap hasil belajar Sejarah Indonesia

Untuk menguji hipotesis yang menyatakan terdapat perbedaan pengaruhyang signifikanantarapenggunaanModelPembelajaran Kooperatif TipeJigsaw dan Model Pembelajaran EkspositoriterhadaphasilbelajarSejarah

IndonesiadigunakananalisisTwo

Way

Anova.Berdasarkanhasil

perhitungananalisisvariasiduajalan, diperolehFob servasi $=$ 10,021 . hasilperhitunganinikemudiandikonsultasikanden gantabelF denganDKpembilang $=1$ danDKpenyebut=29, dantarafsignifikansi 0,05 diperolehF tabel $=4,15$, karenaFobservasi $>$ Ftabelatau10.021>4,15, sehin ggadapatdikatakanterdapat

perbedaanpengaruhyangsignifikanantarapenggu naanModelPembelajaran Kooperatif Tipe Jigsaw danModel Pembelajaran Ekspositoriterhadap hasilbelajarSejarah Indonesia.

b. Perbedaan yang signifikan antara motivasi belajar tinggi dan motivasi belajar rendah siswa terhadap hasil belajar Sejarah Indonesia.

Untuk menguji hipotesis yang menyatakan terdapat perbedaan pengaruh yang signifikan motivasi belajar tinggi dengan rendah terhadap hasil belajar Sejarah Indonesia digunakan analisis variasi Two Way Anova. Berdasarkan hasil perhitungan analisis variasi dua jalan, diperoleh F observasi $=304,098$. Hasil perhitungan ini kemudian dikonsultasikan dengan tabel $\mathrm{F}$ dengan $\mathrm{DK}$ pembilang $=1$ dan DK penyebut $=29$, dan taraf signifikan 0,05 diperoleh $\mathrm{F}$ tabel $=4,15$, karena $\mathrm{F}$ observasi $>\mathrm{F}$ tabel atau 304,098> 4,15 sehingga dapat dikatakan terdapat perbedaan pengaruh yang signifikan motivasi belajar tinggi dengan rendah terhadap hasil belajar Sejarah Indonesia.

c. Interaksi antara model pembelajaran dan motivasi terhadap hasil belajar Sejarah Indonesia.

Untuk menguji hipotesis yang menyatakan terdapat interaksi pengaruh yang signifikan antara penggunaan model pembelajaran dan motivasi terhadap hasil belajar Sejarah Indonesia, digunakan analisis variasi Two Way Anova. Berdasarkan hasil perhitungan analisis variasi dua jalan, diperoleh $\mathrm{F}$ observasi =
84,896. Hasil perhitungan ini kemudian dikonsultasikan dengan tabel $\mathrm{F}$ dengan DK pembilang $=1$ dan DK penyebut $=29$, dan taraf signifikan 0,05 diperoleh Ftabel $=4,15$, karena $\mathrm{F}$ observasi < Ftabel atau 84,896 < 4,15 sehingga dapat dikatakan terdapat interaksi pengaruh yang signifikan antara penggunaan model pembelajaran dan motivasi terhadap hasil belajar Sejarah Indonesia.

d. Perbedaan hasil belajar Sejarah Indonesia antara siswa yang diajar melalui Model Pembelajaran Kooperatif Tipe Jigsaw dengan Model Ekspositori untuk yang memiliki motivasi belajar tinggi

Untuk mengetahui perbedaan pengaruh hasil belajar Sejarah Indonesia antara siswa yang diajar dengan Model Pembelajaran Ekspositori dan Jigsaw bagi siswa yang memiliki motivasi belajar tinggi yang diberikan perlakuan dalam penelitian ini, maka perludilakukan uji lanjut. Uji lanjut digunakan uji Tukey (Tukey' HSD). Berdasarkan Tabel 4. Di atas dapat dikatakan bahwa: antara Model Pembelajaran Ekspositori dan Jigsaw dengan motivasi belajar tinggi memiliki kesamaan bilangan signifikansi sebesar 0,000 dengan Standarerrorofmean(SE) sebesar 1,35. Hal ini berarti, kedua model pembelajaran yang diajarkan pada siswa yang memiliki motivasi tinggi berpengaruh terhadap hasil belajar Sejarah Indonesia.

e. Perbedaan hasil belajar Sejarah Indonesia antara siswa yang diajar melalui Model Pembelajaran Kooperatif Tipe Jigsaw dengan Model Ekspositori untuk yang memiliki motivasi belajar rendah

Untuk mengetahui perbedaan pengaruh model pembelajaran yang diajarkan pada siswa yang memiliki motivasi rendah dapat dilihat dari bilangan signifikansinya sebesar 0,002 dengan Standar error of mean (SE) sebesar 1,58, hal ini berarti kedua model pembelajaran yang diajarkan pada siswa yang memiliki motivasi belajar rendah dapat berpengaruh terhadap hasil belajar Sejarah Indonesia.

f. Perbedaan hasil belajar Sejarah Indonesia antara siswa yang memiliki motivasi belajar tinggi dengan yang rendah untuk yang diajar dengan Model Pembelajaran Kooperatif Tipe Jigsaw

Untuk mengetahui perbedaan pengaruh Model Pembelajaran Kooperatif Tipe Jigsaw 
yang diajarkan pada siswa yang memiliki motivasi tinggi dan rendah dapat dilihat dari bilangan signifikansinya sebesar 0,000 dengan Standar error of mean (SE) sebesar 1,39, hal ini berarti Model Pembelajaran Kooperatif Tipe Jigsaw yang diajarkan pada siswa yang memiliki motivasi belajar tinggi dan rendah dapat berpengaruh terhadap hasil belajar Sejarah Indonesia.

g. Perbedaan hasil belajar Sejarah Indonesia antara siswa yang memiliki motivasi belajar tinggi dengan yang rendah untuk yang diajar dengan Model Pembelajaran Ekspositori.

Untuk mengetahui perbedaan pengaruh Model Pembelajaran Ekspositori yang diajarkan pada siswa yang memiliki motivasi tinggi dan rendah dapat dilihat dari bilangan signifikansinya sebesar 0,000 dengan Standar error of mean (SE) sebesar 1,54, hal ini berarti Model Pembelajaran Kooperatif Ekspositori yang diajarkan pada siswa yang memiliki motivasi belajar tinggi dan rendah dapat berpengaruh terhadap hasil belajar Sejarah Indonesia.

\section{Rangkuman Pengujian Hipotesis}

Dengan membandingkan $\mathrm{F}$ hitung dengan $\mathrm{F}$ tabel maka dapat diketahui keputusan ditolak atau diterimanya hipotesis nihil. Untuk itu secara keseluruhan dapat dilihat rangkuman dari hasil uji statistik secara uji $F$ seperti yang tampak dalam tabel berikut ini

Berdasarkan hasil analisis variansi dua jalan dapat diketahui adanya tidak terdapat interaksi pengaruh yang signifikan antara penggunaan model pembelajaran dan motivasi belajar terhadap hasil belajar Sejarah Indonesia, selanjutnya dilakukan analisis lanjut dengan menggunakan Uji Tukey HSD untuk mengetahui sejauh mana perbedaan Model Pembelajaran Ekspositori dan Model Pembelajaran Kooperatif Tipe Jigsaw terhadap hasil belajar Sejarah Indonesia serta pengaruh motivasi belajar terhadap hasil belajar Sejarah Indonesia. Berdasarkan hasil perhitungan dapat diinterprestasikan hasil sebagai berikut:

1. Terdapat perbedaan mean hasil belajar Sejarah Indonesia dengan penerapan Model Pembelajaran Kooperatif Tipe Jigsaw dan Model Pembelajaran Ekspositori bagi siswa yang memiliki motivasi belajar tinggi $(87,10$ dan 74,22).
2. Terdapat perbedaan mean hasil belajar Sejarah Indonesia dengan penerapan Model Pembelajaran Kooperatif Tipe Jigsaw dan siswa dengan penerapan Model Pembelajaran Ekspositori bagi siswa yang memiliki motivasi belajar rendah $(59,37$ dan 65,66$)$.

3. Terdapat perbedaan mean hasil belajar Sejarah Indonesia antara siswa yang memiliki motivasi belajar tinggi dan rendah dengan penerapan Model Pembelajaran Kooperatif Tipe Jigsaw (87,10 dan 59,37).

4. Terdapat perbedaan mean hasil belajar Sejarah Indonesia antara siswa yang memiliki motivasi belajar tinggi dan rendah dengan penerapan Model Pembelajaran Ekspositori (74,22 dan 65,66).

\section{Pembahasan}

1. Perbedaan Hasil Belajar Sejarah Indonesia Antara yang diajar dengan Model Pembelajaran Kooperatif Tipe Jigsaw dan Model Pembelajaran Ekspositori

Model pembelajaran adalah suatu model yang dipilih guru dalam proses pembelajaran yang dapat memberikan kemudahan atau fasilitas kepada siswa menuju tercapainya tujuan yang telah ditetapkan. Dalam melaksanakan pembelajaran guru harus mampu menggunakan model pembelajaran yang tepat agar tujuan pembelajaran dapat tercapai. Penelitian ini mempelajari sejauh mana model pembelajaran mempengaruhi peningkatan hasil belajar Sejarah Indonesia siswa, dalam hal ini model yang digunakan adalah Model Pembelajaran Kooperatif Tipe Jigsaw dan Model Pembelajaran Ekspositori.

Model Pembelajaran Kooperatif Tipe Jigsaw merupakan model pembelajaran dimana siswa diharapkan dapat bertanggungjawab atas penguasaan bagian materi belajar dan mampu mengajarakan materi tersebut kepada orang lain dalam kelompoknya. Dalam pembelajaran ini siswa dituntut untuk berpikir secara kreatif dan bekerjasama dengan siswa lain. Dalam pembelajaran ini siswa juga harus mampu membahas dan mempertanggungjawabkan tugas yang dikerjakannya. Konsep dalam model pembelajaran ini adalah diharapkan siswa belajar dalam kelompok kecil yang terdiri dari 4-6 orang secara heterogen dan bekerjasama saling ketergantungan yang positif dan bertanggung jawab atas ketuntasan bagian materi pelajaran yang harus dipelajari dan menyampaikan materi tersebut kepada anggota 
kelompok orang lain. Jigsaw di desain untuk meningkatkan rasa tanggung jawab siswa terhadap pembelajarannya sendiri dan juga pembelajaran orang lain. Siswa tidak hanya mempelajari materi yang diberikan, tetapi mereka juga harus siap memberikan dan mengajarkan materi tersebut pada anggota kelompok yang lain. Dengan demikian, "Siswa saling tergantung satu dengan yang lain dan harus bekerja sama secara kooperatif untuk mempelajari materi yang ditugaskan".

Model Pembelajaran Ekspositori juga merupakan pembelajaran konvensional, yaitu suatu model pembelajaran yang mengacu kepada pada penjelasan guru di depan kelas. Siswa dalam suatu kelas tentunya diharapkan mampu memahami dan menelaah materi pelajaran yang disampaikan. Dalam menyampaikan materi guru menjaga bahasa, intonasi suara dan kontak mata dengan siswa tetap dijaga agar perhatian siswa dalam menyimak materi terarah. Strategi Model Pembelajaran Ekspositori untuk mengajarkan materi atau keterampilan guru, kemudian diskusi kelas untuk melatih siswa berfikir tentang topik tersebut, lalu membagi siswa menjadi kelompok belajar kooperatif untuk menerapkan keterampilan yang baru diperolehnya dan membangun pemahamannya sendiri tentang materi pelajaran. Pada model pembelajaran ini tanggung jawab siswa atas materi yang diterima tidak dapat dikembangkan dengan baik karena hanya tergantung pada materi penjelasan guru di depan kelas, siswa bisa saja mengandalkan pada kemampuan teman temannya yang responnya lebih baik, oleh karena itu prestasi siswa yang belajar dengan menggunakan Model Pembelajaran Kooperatif Tipe Jigsaw lebih baik dari pada Model Pembelajaran Ekspositori. Jadi dengan penggunaan model pembelajaran yang tepat maka dapat meningkatkan hasil belajar siswa.

\section{Perbedaan Hasil Belajar Sejarah Indonesia Antara Siswa yang Memiliki Motivasi BelajarTinggi Dengan Rendah.}

Motivasi adalah dorongan-dorongan yang menggerakkan dan mengarahkan kegiatan/tingkah laku seseorang dalam melaksanakan kegiatan belajar. Motivasi memegang peranan penting dalam memberikan gairah atau semangat belajar, sehingga siswa yang bermotivasi tinggi memiliki energi yang banyak untuk melakukan belajar. Seseorang yang memiliki motivasi yang tinggi, rasa ingin tahunya tinggi, berpikir kreatif, ingin selalu berperan, tidak mudah putus asa, tidak malu bertanya, rasa percaya dirinya tinggi dan setiap permasalahan yang ada ingin segera diselesaikan.

Siswa yang memiliki motivasi belajar yang tinggi memiliki keinginan untuk selalu meningkatkan pengetahuannya, dalam mengerjakan tugas selalu bersungguh-sungguh dan berusaha untuk memperoleh hasil yang optimal, memiliki rasa percaya diri yang tinggi dan memiliki dorongan untuk berusaha sendiri dalam mengerjakan sesuatu dan menanyakan hal-hal yang belum jelas atau diketahuinya, sehingga prestasi belajarnya akan cenderung baik. Siswa yang motivasi belajarnya rendah maka cenderung kurang bersemangat dalam melakukan kegiatan pembelajaran, masa bodoh terhadap lingkungan, mudah menyerah terhadap keadaan, tidak berani mengambil resiko dan keputusan rasa percaya dirinya rendah, cenderung tidak mempunyai keinginan untuk meningkatkan prestasi belajarnya sehingga pada akhirnya prestasi belajarnya juga akan kurang baik. Jadi dengan adanya motivasi belajar yang tinggi dari siswa, maka siswa tersebut akan selalu bergairah dan bersemangat dalam belajar sehingga prestasi belajarnya akan lebih baik dibandingkan dengan siswa yang motivasi belajarnya rendah.

\section{Interaksi Antara Model Pembelajaran dan Motivasi Belajar Terhadap Hasil Belajar Sejarah Indonesia.}

Hasil belajar mata pelajaran Sejarah Indonesia sangat ditentukan oleh kegiatan pembelajarannya. Kegiatan pembelajaran ini dipengaruhi oleh banyak faktor diantaranya adalah pendekatan pembelajaran yang digunakan dan motivasi belajar siswa. Guru harus mampu memilih pendekatan mana yang paling efektif dan mampu menempatkan siswa sebagai subjek didik untuk berpikir secara kritis dan analitis serta melatih untuk trampil menentukan dan memecahkan masalah.

Dalam pembelajaran Sejarah Indonesia, hasil belajar siswa sangat ditentukan oleh model pembelajarannya. Hasil belajar siswa akan lebih baik jika digunakan Model Pembelajaran Kooperatif Tipe Jigsaw dibandingkan dengan Model Pembelajaran Ekspositori. Hal tersebut karena dalam pembelajaran dengan Model Pembelajaran Kooperatif Tipe Jigsaw, proses pembelajaran bukan hanya untuk memperoleh pengetahuan saja, tetapi juga untuk memberikan 
tanggungjawab kepada siswa, melatih berpikir intelektual dan merangsang keingintahuan siswa, memaksa siswa berusaha untuk mendapatkan pengetahuan sehingga materi pembelajaran yang dipelajari akan lebih mudah diterima, diingat dan dipahami secara mendalam.

Proses ini perlu didukung oleh motivasi belajar yang dimiliki siswa. Siswa dengan motivasi tinggi jika pembelajarannya menggunakan Model Pembelajaran Kooperatif Tipe Jigsaw akan memperoleh hasil belajar yang lebih tinggi dibandingkan dengan siswa yang memiliki motivasi rendah. Siswa yang pembelajarannya menggunakan Model Pembelajaran Ekspositori dan memiliki motivasi yang tinggi prestasi belajarnya lebih baik daripada yang memiliki motivasi rendah. Hasil penelitian ini menunjukkan adanya interaksi antara model pembelajaran dengan motivasi terhadap hasil belajar. Adanya interaksi disebabkan karena siswa yang memiliki motivasi tinggi dengan model pembelajarannya menggunakan Model Pembelajaran Ekspositori lebih tinggi nilai hasil belajarnya dari pada siswa yang memiliki motivasi rendah pada model pembelajarannya menggunakan Model Pembelajaran Kooperatif Tipe Jigsaw.

\section{Perbedaan hasil belajar Sejarah Indonesia} antara siswa yang diajar melalui Model Pembelajaran Kooperatif Tipe Jigsaw dengan Model Ekspositori untuk yang memiliki motivasi belajar tinggi

Berdasarkan penelitian yang telah dilakukan diketahui bahwa motivasi belajar siswa dengan penerapan Model Pembelajaran Kooperatif Tipe Jigsaw tergolong kedalam kategori sangat tinggi. Hal ini dikarenakan pengaruh penggunaan Model Pembelajaran Kooperatif Tipe Jigsaw dalam kegiatan pembelajaran. Hasil penelitian ini menguatkan pandangan Purwanto bahwa motivasi merupakan suatu usaha yang didasari untuk menggerakkan, mengarahkan, dan menjaga tingkah laku seorang anak agar dia terdorong untuk bertindak melakukan sesuatu sehingga mencapaikan hasil. Siswa yang memiliki motivasi sangat tinggi akan terdorong untuk belajar lebih keras agar mencapai hasil yang semaksimal mungkin. Siswa yang memiliki motivasi belajar yang sangat tinggi memiliki hasrat yang kuat untuk berhasil, mempunyai dorongan dan kebutuhan dalam belajar, mempunyai harapan dan cita-cita masa depan yang baik. Siswa yang memiliki motivasi belajar yang sangat tinggi selalu berkeinginan untuk melakukan motivasi belajar yang lebih giat

Motivasi belajar siswa dengan Model Pembelajaran Kooperatif Tipe Jigsaw tergolong sangat tinggi karena pada model pembelajaran ini memiliki beberapa tahapan dalam pembelajaran sehingga membuat siswa termotivasi dalam mengikuti pembelajaran. Salah satu alasan siswa termotivasi dalam Model Pembelajaran Kooperatif Tipe Jigsaw karena pembelajarannya lebih terpusat pada siswa, sehingga tidak berharap dengan apa yang disampaikan oleh guru saja, tetapi siswa sendiri harus mencari informasi yang lebih banyak dari berbagai referensi sehingga pelajaran yang diajarkan lebih mudah dipahami.

Berdasarkan penjelasan di atas yang sesuai dengan hipotesis penelitian bahwa Model Pembelajaran Kooperatif Tipe Jigsaw lebih tinggi capaian hasil belajarnya dibandingkan dengan siswa yang menerima materi pelajaran Sejarah Indonesia dengan Model Pembelajaran Ekspositori sehingga dalam hipotesis ini dinyatakan bahwa terdapat perbedaan pengaruh terhadap hasil belajar Sejarah Indonesia antara siswa yang diajarkan dengan Model Pembelajaran Kooperatif Tipe Jigsaw dan Model Pembelajaran Ekspositori bagi siswa yang memiliki motivasi belajar tinggi.

\section{Perbedaan hasil belajar Sejarah Indonesia antara siswa yang diajar melalui Model Pembelajaran Kooperatif Tipe Jigsaw dengan Model Ekspositori untuk yang memiliki motivasi belajar rendah}

Penelitian ini diawali dengan pelaksanaan pretest dan di akhiri dengan posttest pada kelas eksperimen dan kelas kontrol. Tujuan dilakukan pretest ini untuk mengetahui kemampuan awal pemahaman awal siswa. Setelah pretest selesai selanjutnya kelas eksperimen dan kelas kontrol masing-masing melaksanakan proses pembelajaran. Untuk kelas eksperimen pembelajaran dilakukan dengan menggunakan Model Pembelajaran Koopertaif Tipe Jigsaw sedangkan kelas kontrol menggunakan Model Pembelajaran Ekspositori. Hal ini dilakukan untuk melihat hasil belajar Sejarah Indonesia siswa, yang dipelajarinya dengan model pembelajaran yang berbeda. Secara keseluruhan rangkuman nilai rata-rata posttest hasil belajar Sejarah Indonesia yang diajar dengan dua model pembelajaran tersebut. 
6. Perbedaan hasil belajar Sejarah Indonesia antara siswa yang memiliki motivasi belajar tinggi dengan yang rendah untuk yang diajar dengan Model Pembelajaran Kooperatif Tipe Jigsaw

Pengaruh motivasi terhadap seseorang tergantung seberapa besar motivasi itu mampu membangkitkan motivasi seseorang untuk bertingkat laku. Dengan motivasi yang besar, maka seseorang akan melakukan sesuatu pekerjaan dengan lebih memusatkan pada tujuan dan akan lebih intensif pada proses pengerjaannya. Dalam kegiatan belajar, motivasi dapat dikatakan sebagai keseluruhan daya penggerak di dalam diri seseorang yang menimbulkan kegiatan belajar, yang menjamin kelangsungan dari kegaitan belajar dan memberikan arah pada kegiatan belajar, sehingga tujuan yang dikehendaki oleh subyek belajar itu dapat tercapai.

Motivasi belajar siswa dapat dilihat perbedaannya ketika diberikan materi ajar dengan menggunakan model pembelajaran. Penerapan model pembelajaran dihipotesis ini adalah Model Pembelajaran Kooperatif Tipe Jigsaw yang diberikan kepada siswa yang memiliki motivasi belajar tinggi dan rendah, dengan menerapkan model pembelajaran ini kedua motivasi belajar siswa dapat dilihat perbedaannya dengan perolehan mean 87,10 untuk Model Pembelajaran Kooperatif Tipe Jigsaw dengan motivasi belajar tinggi sedangkan mean 59,37 untuk Model Pembelajaran Kooperatif Tipe Jigsaw dengan motivasi rendah.

Kedua motivasi belajar tersebut dapat dilihat pengaruhnya terhadap hasil belajar Sejarah Indonesia dengan melihat signifikansinya sebesar 0,00. Dari nilai signifikansi ini dapat disimpulkan bahwa terdapat perbedaan pengaruh hasil belajar Sejarah Indonesia antara siswa yang memiliki motivasi belajar tinggi dan rendah yang diajar dengan Model Pembelajaran Kooperatif Tipe Jigsaw karena nilai signifikansinya dibawah nilai $\alpha 0,05$.

\section{Perbedaan hasil belajar Sejarah Indonesia} antara siswa yang memiliki motivasi belajar tinggi dengan yang rendah untuk yang diajar dengan Model Pembelajaran Ekspositori

Pembelajaran Ekspositori adalah strategi yang menekankan kepada proses penyampaian materi secara verbal dari seorang guru kepada sekelompok siswa dengan maksud agar siswa dapat menguasai materi pelajaran secara optimal. Strategi pembelajaran ekspositori adalah kerangka konseptual yang melukiskan prosedur dalam mengorganisasikan pengalaman belajar untuk mencapai tujuan tertentu dan berfungsi sebagai pedoman bagi perancang pembelajaran, lingkungan pembelajaran dan pengelolaan kelas. Strategi pembelajaran ekspositori lebih mengarah kepada tujuannya dan dapat diajarkan atau dicontohkan dalam waktu yang relatif pendek.

Perbedaan pengaruh motivasi belajar tinggi dan rendah terhadap hasil belajar Sejarah Indonesia dapat terlihat dari adanya penerapan model pembelajaran. Model pembelajaran yang dimaksudkan dalam hipotesis ini adalah Model Pembelajaran Ekspositori. Perbedaan pengaruhnya dapat dilihat dari perolehan nilai mean bagi siswa yang memiliki motivasi belajar tinggi adalah 74,22 sedangkan nilai mean 65,66 bagi siswa yang memiliki motivasi belajar rendah, kedua nilai mean dari hasil belajar siswa yang memiliki motivasi belajar tinggi dan rendah sudah diberikan materi ajar dengan menggunakan Model Pembelajaran Ekspositori. Perbedaan pengaruhnya yang terdapat dalam hipotesis ini dapat diperjelas dengan perolehan signifikansinya sebesar 0,000. Jadi kesimpulannya terdapat perbedaan pengaruh hasil belajar Sejarah Indonesia bagi siswa yang memiliki motivasi belajar tinggi dan rendah untuk yang diajar dengan menggunakan Model Pembelajaran Ekspositori.

\section{SIMPULAN DAN SARAN}

Berdasarkan hasil analisis data dan pembahasan yang telah diuraikan sebelumnya, maka dapat diambil kesimpulan sebagai berikut:

1. Ada perbedaan hasil belajar Sejarah Indonesia antara siswa yang diajar dengan menggunakan Model Pembelajaran Kooperatif Tipe Jigsaw dan Model Pembelajaran Ekspositori. Hasil belajar Sejarah Indonesia pada kelompok siswa yang belajar dengan menerapkan Model Pembelajaran Kooperatif Tipe Jigsaw lebih baik dari pada kelompok siswa yang belajar dengan menerapkan Model Pembelajaran Ekspositori.

2. Ada perbedaan hasil belajar Sejarah Indonesia antara siswa yang memiliki motivasi belajar yang tinggi dan rendah terhadap prestasi belajar Sejarah Indonesia. Hasil belajar siswa yang memiliki motivasi 
belajar tinggi lebih baik daripada siswa yang memiliki motivasi belajar yang rendah.

3. Ada interaksi antara penggunaan model pembelajaran dan motivasi belajar siswa terhadap hasil belajar Sejarah Indonesia. Rata rata nilai hasil belajar Sejarah Indonesia siswa yang memiliki motivasi belajar tinggi dan menggunakan Model Pembelajaran Kooperatif Tipe Jigsaw lebih tinggi dari pada rata rata nilai hasil belajar siswa yang menggunakan Model Pembelajaran Ekspositori. Tetapi rata rata nilai hasil belajar Sejarah Indonesia siswa yang memiliki motivasi rendah dan menggunakan Model Pembelajaran Ekspositori juga lebih tinggi dibandingkan dengan siswa bermotivasi rendah yang menggunakan Model Pembelajaran Kooperatif Tipe Jigsaw. Hal ini menunjukkan bahwa siswa yang memiliki motivasi belajar tinggi sangat terpengaruh oleh model pembelajarannya.

4. Ada perbedaan hasil belajar Sejarah Indonesia antara siswa yang diajar dengan Model Pembelajaran Kooperatif Tipe Jigsaw dengan Model Pembelajaran Ekspositori bagi siswa yang memiliki motivasi belajar tinggi. Rata-rata nilai hasil belajar Sejarah Indonesia lebih tinggi bagi siswa yang diajar menggunakan Model Pembelajaran Kooperatif Tipe Jigsaw dibanding Model Pembelajaran Ekspositori yang sama-sama diajarkan kepada siswa yang memiliki motivasi belajar tinggi.

5. Ada perbedaan signifikan hasil belajar Sejarah Indonesia antara yang diajar menggunakan Model Pembelajaran Kooperatif Tipe Jigsaw dengan Model Pembelajaran Ekspositori bagi siswa yang memiliki motivasi belajar rendah. Dalam hal ini, rata-rata nilai hasil belajar Sejarah Indonesia lebih tinggi dengan menggunakan Model Pembelajaran Ekspositori dibanding dengan Model Pembelajaran Kooperatif Tipe Jigsaw.

6. Ada perbedaan signifikan hasil belajar Sejarah Indonesia antara siswa yang memiliki motivasi belajar tinggi dan rendah bagi peserta didik yang diajar menggunakan Model Pembelajaran Kooperatif Tipe Jigsaw terhadap hasil belajar Sejarah Indonesia. Siswa yang memiliki motivasi belajar tinggi lebih baik rata-rata nilai hasil belajarnya dibanding siswa yang memiliki motivasi belajar rendah.
7. Ada perbedaan pengaruh hasil belajar Sejarah Indonesia antara siswa yang memiliki motivasi belajar tinggi dan rendah bagi siswa yang diajar menggunakan Model Pembelajaran Ekspositori. Nilai rata-rata hasil belajar Sejarah Indonesia lebih tinggi yang memiliki motivasi belajar tinggi dibanding dengan siswa yang memiliki motivasi belajar rendah.

\section{Saran}

Berdasarkan kesimpulan dan implikasi dari penelitian ini, maka dapat diajukan saran-saran sebagai berikut:

1. Guru Sejarah Indonesia dalam melaksanakan kegiatan pembelajaran sebaiknya menggunakan Model Pembelajaran Kooperatif Tipe Jigsaw, hal ini karena dari hasil penelitian menunjukkan bahwa Model Pembelajaran Kooperatif Tipe Jigsaw lebih baik dari Model Pembelajaran Ekspositori.

2. Dalam pembelajaran Sejarah Indonesia, guru Sejarah Indonesia di tingkatan SMA/MA sebaiknya :

a. Merancang model pembelajaran yang menarik dan menyenangkan dengan menerapkan Model Pembelajaran Jigsaw sehingga dapat membantu siswa untuk menguasai materi pelajaran dengan baik.

b. Menumbuhkan semangat dan gairah belajar siswa melalui Model Pembelajaran Jigsaw.

c. Memberikan kesempatan kepada siswa untuk mau melakukan, mencoba dan menyelesaikan persoalan yang berkaitan dengan Sejarah Indonesia agar siswa dapat meningkatkan rasa percaya dirinya.

d. Mengendalikan suasana pembelajaran agar pembelajaran tetap dalam suasana yang menyenangkan.

e. Membentuk kelompok yang beranggotakan sesuai dengan jumlah permasalahan yang akan dibahas agar lebih mengoptimalkan keterlibatan siswa dalam kegiatan diskusi kelompok.

3. Banyak variabel penelitian yang belum diungkap secara mendalam dalam penelitian ini, misalnya dalam hal pengukuran hasil belajar hanya mengukur aspek kognitif siswa. Oleh karena itu disarankan untuk diadakan penelitian lebih lanjut yang bertujuan untuk meningkatkan aspek afektif dan psikomotor siswa sehingga akan lebih lengkap dalam menilai kompetensi yang dimiliki oleh siswa. 


\section{DAFTAR RUJUKAN}

Akhmad

Sudrajat.2008.

"CooperativeLearningTeknik Jigsaw" http://akhmad

sudrajat.wordpress.com.Diakses 2

Januari 2017.

Basleman, A \& Mappa, S. 1994. Teori Belajar Orang Dewasa. Jakarta: Proyek Pembinaan dan Peningkatan Mutu Tenaga Kependidikan Direktorat Jenderal Pendidikan Tinggi Depdikbud.

Budiningarti,Hermin. 1998. Pengembangan Strategi pembelajaran Kooperatif Tipe JigsawPada Pembelajaran Fisika di SMU.Tesis. Tidak diterbitkan. Surabaya: IKIP Surabaya.

Dimyati dan Mudjiono. 2006. Belajar dan Pembelajaran. Jakarta: Rineka Cipta.

Hamalik, Oemar. 2007. Proses Belajar Mengajar. Jakarta: Bumi Aksara

Hasan, H. S. 1996. Pendidikan Ilmu Sosial (Buku I dan Buku II). Bandung: FPIPS IKW Bandung.

Hariyanto. 2000. Perbandiangan Hasil Belajar Matematika antara Siswa yang Pembelajarannya Menggunakan Model Kooperatif Tipe Jigsaw dengan Model Tradisional di Kelas II MAN Jember. Tesis.Tidak diterbitkan. Bandung: PPS UP

Hudoyo, H. 1979.Pengembangan Kurikulum Matematika \& Pelaksanaanya di Depan Kelas. Surabaya: Usaha Nasional.

Ibrahim, H. M., dkk. 2000. Pembelajaran Kooperatif. Surabaya: UNESA University Press.

Kasmadi, Hartono. 2001. Pengembangan Pembelajaran dengan Pendekatan Model-Model Pengajaran Sejarah. Semarang: PT. Prima Nugraha Pratama.

Mudyahardjo, Redja. 2002. Pengantar Pendidikan: Sebuah Studi awal tentang dasar-dasar pendidikan pada umumnya dan pendidikan di
Indonesia. Jakarta: Raja Grafindo Persada.

Nur, M. 2005. Pembelajaran Kooperatif. Jawa Timur: DEPDIKNAS.

Palardi. 1975. Dalam Drs. Ali Imron, M.Pd, Belajar dan Pembelajaran. Jakarta: PT. Dunia Pustaka Jaya.

Purwanto, M. Ngalim. 1996. Psikologi Pendidikan. Bandung: Remaja Rosdakarya

Ratumanan, T.G. 2002. Model Pembelajaran Interaktif dengan Setting Kooperatif. Surabaya: PPS Universitas Surabaya

Sardiman, A.M. 2005. Interaksi dan Motivasi Belajar Mengajar. Jakarta: Rajawali Press

Shabri, H. A. (2005). Strategi Belajar Mengajar Micro Teaching. Jakarta: Quantum Teaching.

Silberman, Mel. 1998. Active Learning. Jakarta: Yappendis

Slameto. 1987. Belajar dan Faktor-Faktor yang Mempengaruhi Hasil Belajar. Salatiga: Bina Aksara

Slameto. 2003. Belajar dan Faktor-Faktor yang Mempengaruhinya. Jakarta. Rineka Cipta

Slavin. 1995. Cooperative Learning Theory, Research and Practice. Second Edition. Massachusetts: Allyn and Publishers.

Soewarso. 2000. Cara-Cara Penyampaian Pendidikan Sejarah Untuk Membangkitkan Minat Peserta Didik Mempelajari Bangsanya. Jakarta: DEPDIKNAS

Sudjana, N. (2005). Penilaian hasil proses belajar mengajar. Bandung: PT Remaja Rosdakarya.

Sugiyono. 2007. Metode Penelitian Pendidikan Pendekatan Kuantitatif, Kualitatif, dan $R$ \& D. Bandung: Alfabeta

Surya, Muhammad. 2004. Psikologi Pembelajaran dan Pengajaran. Bandung: Pustaka Bani Quraisy

Suryabrata, S. (2001). Psikologi pendidikan. Yogyakarta: Universitas Gadjah Mada. 
Suryabrata, Sumadi. 1994. Psikologi Pendidikan. Jakarta: Raja Grafindo Persada

Sutanto, A. 2001. Pembelajaran Kooperatif. Semarang: Balai Penataran Guru Semarang.

Tadjab, MA. 1994. Ilmu Pendidikan. Surabaya: Abditama

Tamburaka, Rustam E. 1999. Pengantar Ilmu Sejarah, Teori Filsafat Sejarah, Sejarah Filsafat dan Iptek. Jakarta. Rineka Cipta

Trianto, 2007. Model-Model Pembelajaran Inovatif Berorientasi konstruktivistik. Jakarta: Prestasi Pustaka.

Widja, I Gde. 1989. Dasar-Dasar Pengembangan Strategi dan Metode Pengajaran. Jakarta: Depdiknas. 